\title{
The Structural Dimensions of the Political Institutions of the State; Theorizing through the Management and Institutional Theory: Proposed Boarding
}

\author{
Alejandro Sanchez Garcia \\ University Of Guanajuato, Guanajuato, Mexico \\ Email: asanchezg.gcg@gmail.com
}

Received 28 July 2014; revised 17 September 2014; accepted 2 October 2014

Copyright (C) 2014 by author and Scientific Research Publishing Inc.

This work is licensed under the Creative Commons Attribution International License (CC BY). http://creativecommons.org/licenses/by/4.0/

\section{(c) (i) Open Access}

\begin{abstract}
Our research is to review two significant models for analyzing structures of institutions, which have made themselves, first Henry Mintzberg, with its model of key elements of the structures, and on the other hand, Meyer \& Rowan with his model of rationalized institutional structures. The discourse of previous authors, resides to sustain what for them are the most important or essential dimensions of the structures in the institutions. With up to us, we try to review the arguments of both models and their contribution to institutional theory to develop on our part, discursive lines supported in said Institutional Theory, those that we believe which should be the structural dimensions of the institutions policies, and should be reviewed by anyone who makes part of itself, the study of the structures of the State political Institutions, which we consider, are institutional political dimensions, which will allow the political organization par excellence, its own stability, adaptation and arrangement, through the design of incentives or sanctions reflected in their own Political Institutions.
\end{abstract}

\section{Keywords}

State Political Institutions, Structural Dimensions of Political Institutions, Management, Institutional Theory, Fundamentals Structures, Rationalized Institutional Structures

\section{Introduction}

In this template, throughout the social and political debate, there have been coincidences and divergences of 
what is a organization and an institution. However, to achieve the objectives of our study, we will address the analysis of the institutions in the light of the institutional theory. That is, terms of March and Olsen (1984) to understand the institutions as a "set of rules and routines that define interconnected right actions in terms of relations between roles and situations" (738-749).

In this research, we are interested in studying how the New Institutional Theory provides elements to explain the dynamics of rational actors who are part of the policy institutions. Paraphrasing McFarland (2014): "New institutionalism emphasizes the pervasive influence of institutions on human behavior through rules, norms and conceptual frameworks (Video Lecture 21)" and on the latter factors, we intend to strengthen argument, for our part in addressing the concept or idea of some structural dimensions of Political Institutions, as our discourse that has developed around the discussion of the institutional theory contribution.

As research hypothesis we argue that, depending on how we conceive the dimensions of the structures of the institutions will be the way of the formation of the collectivized decision taken at that institution, so it is important to review the significant approaches existing on the subject, from the standpoint of management and from the angle of institutional theory, offering valuable contributions Mintzberg, and Meyer \& Rowan.

\section{Political Institutions}

It has been argued that Political Institutions are interconnected set of rules and routines that define the right actions in terms of relations between roles and situations (Peters, 2004).

The actors that define those roles and situations do not act individually but they do so collectivized. It is the institution itself, the decision collectivized.

But rationalized and impersonal nature which is proper to the institutional collectivized decision develops within an organizational structure, a structure that acquires in most of the occasions, formal features that allow fluidity of relationships, as well as coordination and control them.

It is important to focus or lens through which institutions are reviewed as well as models that are made depending on your starting point. Whether from the angle of the "Theory of Political Management" Henry Mintzberg, where displays organizations and the essence of the structure connected via management tool, or, from the perspective of the "Theory of Bureaucracy Policy" Guy Peters, where contends that even if it was considered a public administration and related processes rules and structures; in reality includes political elements.

In a word: "The management has elements of Politics and Politics has elements of management".

\section{The Management: Mintzberg and Model Key Elements of Structures}

For Professor of Management Studies (Strategy and Organization) from McGill University (2002), the organizational structure can be defined as "the set of all the ways in which the work is divided in different tasks, then getting the coordination of them (p. 26)".

As we see from for Mintzberg are two key elements of organizations: division of work and coordination.

The mentioned Ph.D. MIT Sloan School of Management (2002) states that there are five control mechanisms seem to explain the fundamental ways in which organizations coordinate their work:

o Mutual Adaptation;

o Direct Supervision;

o Normalization of work processes;

o Normalization of work results; and

o Normalization of Worker Skills.

For Mintzberg five elements mentioned above, should be considered as the key elements of the structure.

By Mutual Adaptation, coordination of work is achieved by simple informal communication.

This control mechanism is borne directly by the operator and given in the simplest organizations, as shown in the following Figure 1.

In terms of public policy, we could say, theorizing to Mintzberg, that mutual adaptation is the one between citizens of the same state (Figure 2).

When Mutual Adaptation is not sufficient to coordinate and control the work, it is important the Direct Supervision.

The Direct Supervision coordinating work forces, when a person responsible for the work of others, giving them instructions and controlling their actions, as shown in Figure 3.

In the same previous tessitura, in terms of public policy, theorizing to Mintzberg, one can say that the Direct 


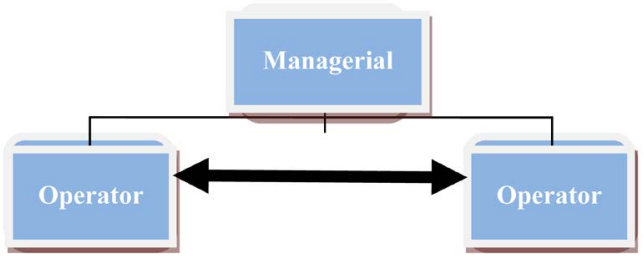

Figure 1. Mutual adaptation (In the Company).

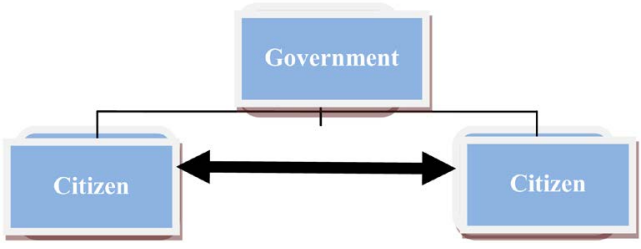

Figure 2. Mutual adaptation (In the State).

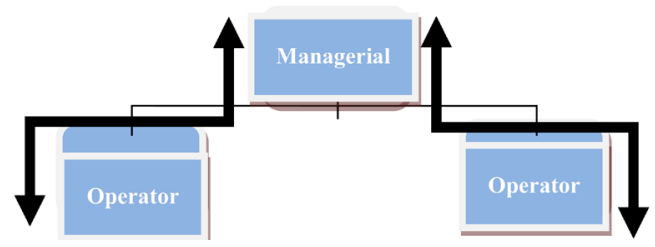

Figure 3. Direct supervision (In the Company).

Supervision is given by government to its citizens, as exemplified in Figure 4.

Paraphrasing Mintzberg (2002) exemplified that when there is an absence of mutual adaptation, or there is a lack of supervision, through the structure, the work can be normalized. The coordination of the parties is incorporated in the program of work that is reflected in the norm. In organizations there may be three types of normalization:

o Normalization of Work Processes;

o Normalization of Work Results; and

o Normalization of Worker Skills.

For the first, that is, for the Normalization of Work Processes, normalize when the work content is specified, scheduled. Require little direct supervision and there will be some informal communication with peers, except for the most necessary.

By Normalization of Work Results, it is understood when the results are specified, i.e., in our terms, means that the results are normalized when the end or purpose to be achieved to avoid deviations in the goal or objective is regulated.

The same way, Normalization of Worker Skills is when it has been specified the type of preparation required for the performance of work. The standardized skills deal with much of the coordination of work.

\section{1) POLITICAL THEORY: John W. Meyer \& Brian Rowan, Model of Rationalized Institutional Struc- tures}

The professors of the Stanford University, argues that institutions are myths that make both more necessary and easier to create formal organizations.

For them, the elements that organizations are built are dispersed the social scene, discoursing that just need a bit of entrepreneurial energy to be integrated into a structure.

The most important elements or binders institutionalized rational structures, to Meyer \& Rowan (1977) are:

a) INSTITUTIONAL RULES. As rationalized institutional rules arise in given domains of work activity, formal organizations form and expand by incorporating these rules as structural elements.

b) MODERNIZATION OF THE SOCIETY. The more modernized the society, the more extended the rationalized institutional structure in given domains and the greater the number of domains containing rationalized institutions. 


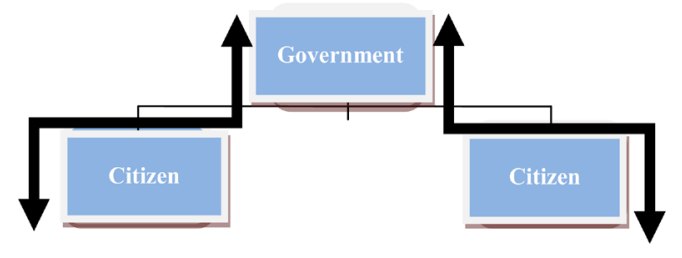

Figure 4. Direct supervision (In the State).

This is summarized by the authors in Figure 5 .

From the review of the two structural dimensions of rational institutionalized organizations proposed by Meyer \& Rowan, network building and the environment are important for defining structures institutionalized organizations; states that organizational structures arise in many different contexts, and it is necessary to take these external elements to legitimize the adopted structure.

\section{2) PROPOSED BOARDING: Structural Dimensions of Political Institutions}

Guy Peters (2004) argues in relation to the call Legalism, the first determining characteristic of the old institutionalism is that the law has an important role, as for most European countries [I would add: and American] law is the element essential of the exercise of power, playing an important role as a fundamental tool of the government to influence the behavior of citizens, as well as Anglo-American thinking instruments on the public sector; but to deal with the legislation, as well Peters argues, is just the beginning.

However, as part of what might be called neo-institutional normativism, we intend to move the role of the law to grant it to the Constitution as a unifying element of the fundamental political principles of a State, and as an element that recognizes the fundamental rights most important citizens.

As argues Zagrebelsky (2007):

The law, a time exclusive measure of all things in the area of law and yields to the Constitution itself becomes the object of measurement. It is dethroned in favor of a higher instance. And this highest authority now assumes the important role of maintaining peace and united whole societies divided inside and concurrent. A nonexistent function in another time, when the political society was, and assumed it was in itself, united and peaceful. In the new situation, the principle of constitutionality is the one to ensure the achievement of this goal of unity (pp. 21-45).

In this situation, highlights the total subjugation of government activity to the Constitutional State and not only the rule of law. This implies that public administration traditionally bounded by the Administrative Law Control of Legality, safeguarded general interests whose public service was subject only to the law, but leaving aside the opportunity to develop a par excellence constitutional role of government in favor of fundamental rights of citizens.

For us are Structural Dimensions of Political Institutions as follows:

a) Institutional Constitutionalization;

b) Institutional Policy Centralization;

c) Institutional Policy Specialization;

d) Spatial Dispersion Policy in Institutions;

e) Institutional Political Span of Control.

a) Institutional Constitutionalization. The constitutionalization as one of the structural dimensions of Political Institutions, involves the degree to which they are formalized at the constitutional level processes and rules of public organizations, i.e., within the scope of the Basic Law (Constitution) are embodied processes, procedures, rules and policy institutions, meaning "political" those fundamental decisions for the state. When an institution is constitutionalized, becomes Institution Policy.

A greater institutional constitutionalization, greater control and supervision of political power, and greater citizen trust in government; but must be detected when constitutionalise an institution and when to not, because not all issues must be enshrined in the constitution, if not only the fundamental policy of the state. It must be about fundamental political decisions (form of government, separation of powers, exercising executive, legislative, judicial and autonomous of the branches of government, Federalism, Republicanism, representation, democracy, electoral systems and party systems).

b) Institutional Policy Centralization. For us, refers to the concentration of political power in the institutions at the heart of making fundamental policy decisions. 


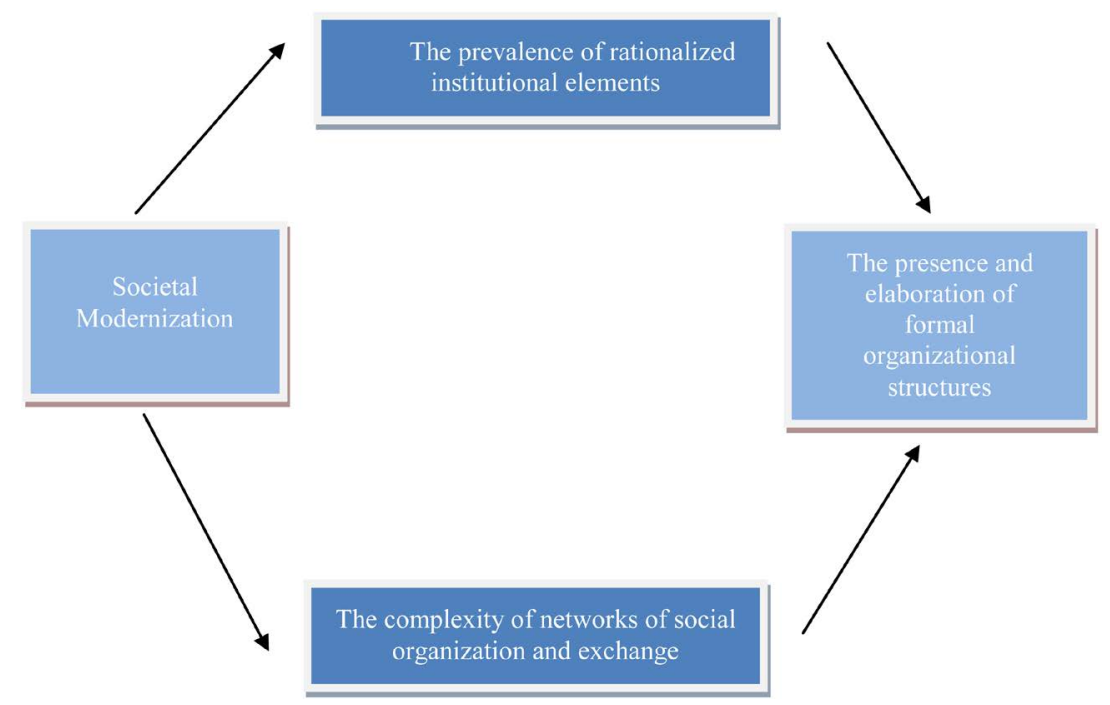

Figure 5. The origins and elaboration of formal organizational structures.

The degree of institutional political centralization, is the level and variety of participation in strategic decisions by the institutions in relation to the total number of institutions that interact in the state.

As an example we may refer to the creation of autonomous constitutional agencies such as the autonomous institutes election in some countries, banks Autonomous National, Autonomous Colleges, involve a lesser degree of political centralization, to undermine the basic function of the executive in presidential systems, or Prime Minister, in parliamentary systems.

c) Institutional Policy Specialization. Define the Institutional Policy specialization as horizontal differentiation of institutional political tasks. The more differentiated and/or policies are specialized institutions, will be more effective, but more demotivating citizen participation.

Take for example the creation of various specialized agencies (political structures) that would meet the agenda of "executive power" in energy and telecommunications matters; specialized exist constitutionally political bodies to meet in a more effective way of technical issues that concern them, however, citizen participation tends to decrease these bodies serve as arenas for technical discussion. Decisions can be technocratic but may have little social legitimacy.

- A greater specialization of Political Institutions, lower political centralization.

- A less specialized, less effective.

d) Spatial Dispersion Policy Institutions. Involves the number of political tasks that may be dispersed in the state political space, in accordance with its constitutional functions, as well as the separation of centers of power, or political tasks.

\section{- A dispersion greater Political Institutions, lower efficiency in decision-making.}

An example of this means that according to the constitutional functions, the judiciary is intended to resolve disputes, that is, declare or decide on the right through the creation of courts. If there are courts created not only in the field of the judiciary, but under other powers such as the executive (administrative courts, labor, agrarian, tax), there will be institutional space policy dispersion of the jurisdictional function of the State, this function to be shared between two powers: Executive and Judicial.

- A higher spatial political centralization, more efficient decision making.

e) Institutional Political Span of Control. It is defined as the number of institutions that can effectively control a person making government decisions.

Example of this is found that in the area of "executive power", other central administrative agencies are created to manage public affairs, in some systems called state secretariats in some other systems are called ministries.

The Institutional Political Span of Control is the effective number of government agencies that as a President can control effectively, therefore depending on the amplitude of the span of control and functions that have been assigned to those units centralized and decentralized, dependent on a head of "executive power".

The above structural dimensions of Political Institutions can represent through Figure 6. 


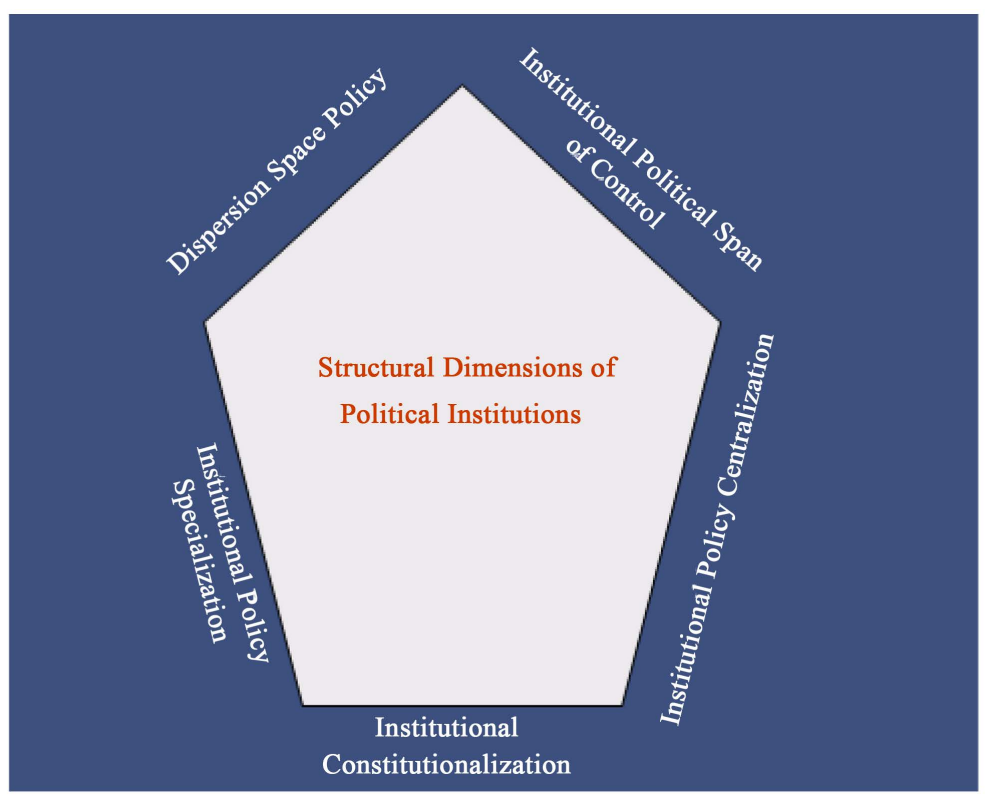

Figure 6. Structural dimensions of Political Institutions.

\section{Conclusion}

Addressing the essential dimensions of the structures in the institutions has been based on the elements that are studied and the position of each of the academic trends.

Mintzberg's model offers contribute to institutional theory, the study of structures in response to internal elements of organizations: 1) Mutual Adaptation; 2) Direct Supervision; 3) Normalization of work processes; 4) Normalization of work results; and 5) Normalization of the skills of the worker.

An analysis of the five control mechanisms organizations Mintzberg, same as the above author beliefs are the fundamental elements of the structures, it is appreciated that these elements are substitutable one another, depending on the type and size of organization, as the rotation, whether commercial, industrial or service, public or private; organizations could focus on using simpler mechanisms or coordination complex, because under certain conditions of size, time, manner and place, organizations will prefer one or several of them, or use five at a time, hence being replaceable key elements of the structures according to this model.

The Mintzberiano model can be applied in the field of Political Theory in the case of the relationships that exist between those citizens interse and horizontal in a given democratic state, and between these organizations and the organized civil society (NGO'S) and its vertical relationship that they have with the government; in the same way, the role that the latter plays in formulating and implementing public policy.

However, the above are subjective elements studied, that is, mutual adaptation and direct supervision tend to be subjective elements of institutions, while normalization tends to be an element of objective nature. Meanwhile, institutional structures tend to conform more objective, tasteless, colorless and odorless (figuratively), to provide support or general parameters must travel in the policy decisions of fundamental political elements.

Meyer \& Rowan, through its Model of Rationalized Institutional Structures, contribute to the Political Theory, external or environmental support in which the institutions are developed: Rules and Institutional Modernization of the Society.

Important distinction is that, while for Normalization Mintzberg, i.e. the issue of institutional rules is designed to regulate work processes, results and skills to Meyer \& Rowan, the issue of institutional rules is intended to maintain compliance ceremonial (ritual rationalized inspection and evaluation) and protect their formal structures from the uncertainties of technical activities.

Mintzberg pertains that, according to their model, the internal elements considered fundamental structures of organizations; Meyer and Rowan, in his model give prominence to external and environmental factors, since even when referring to the existence of institutional rules, they are incorporated outside of the organizational structure to be institutionalized. 
For our part, through the model of structural dimensions of Political Institutions, we intend to provide a reflection to the discourse of institutional theory taking as many objective factors as part of the structures of the institutions, i.e., trying to provide arguments for withstand an Objective Theory of Institutional Structures, with the premises of the structural dimensions: 1) Institutional Constitutionalization; 2) Institutional Policy Centralization; 3) Institutional Policy Specialization; 4) Spatial Dispersion Policy in the institutions; and 5) Institutional Political Span of Control.

Finally we consider that the institutional theory to the development of their models will focus on those streams rather than try to design rules that dictate towards righteous actions, in terms of relations between roles and situations holistically, i.e. considering subjective elements and objectives of the institutions, since the formation of collectivized decision cannot be taken without pause or thoughtful reflection of the integral elements that constitute Political Institutions.

\section{References}

March, J., \& Olsen, J. P. (1984). The New Institutionalism: Organizational Factors in Political Life. American Political Science Review, 78, 738-749. http://dx.doi.org/10.2307/1961840

McFarland, D. A. (2014). University Stanford (Producer): Program Organizational Analysis, Lecture 21-Institucions and Organizational Legitimacy-Part 1. https://class.coursera.org/organalysis-002/lecture/160

Meyer, J., \& Rowan, B. (1977). Institutionalized Organizations: Formal Structure as Myth and Ceremony. American Journal of Sociology, 83, 340-363. http://dx.doi.org/10.1086/226550

Mintzberg, H. (2002). The Structuring of Organizations: ARIEL.

Peters, G. B. (2004). The New Institutionalism. Barcelona: GEDISA.

Zagrebelsky, G. (2007). The Rule of Law to the Constitutional State. The Ductile Law. Law, Rights, Justice. Madrid: TROTA. 
Scientific Research Publishing (SCIRP) is one of the largest Open Access journal publishers. It is currently publishing more than 200 open access, online, peer-reviewed journals covering a wide range of academic disciplines. SCIRP serves the worldwide academic communities and contributes to the progress and application of science with its publication.

Other selected journals from SCIRP are listed as below. Submit your manuscript to us via either submit@scirp.org or Online Submission Portal.
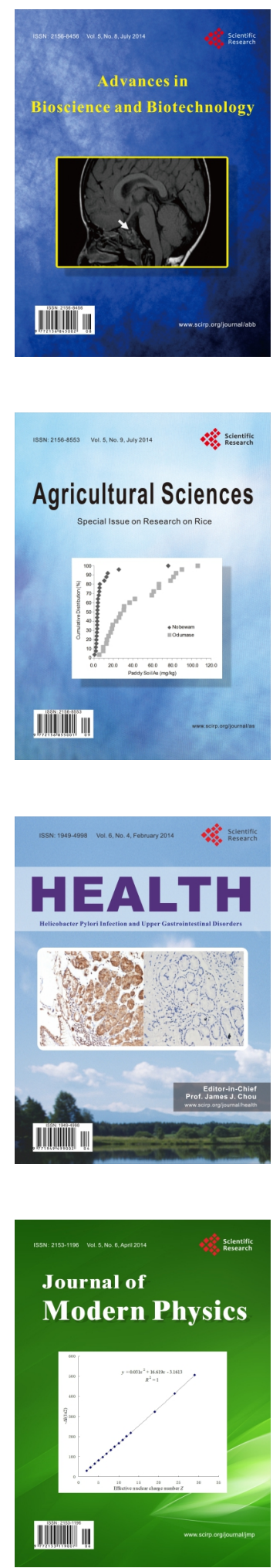
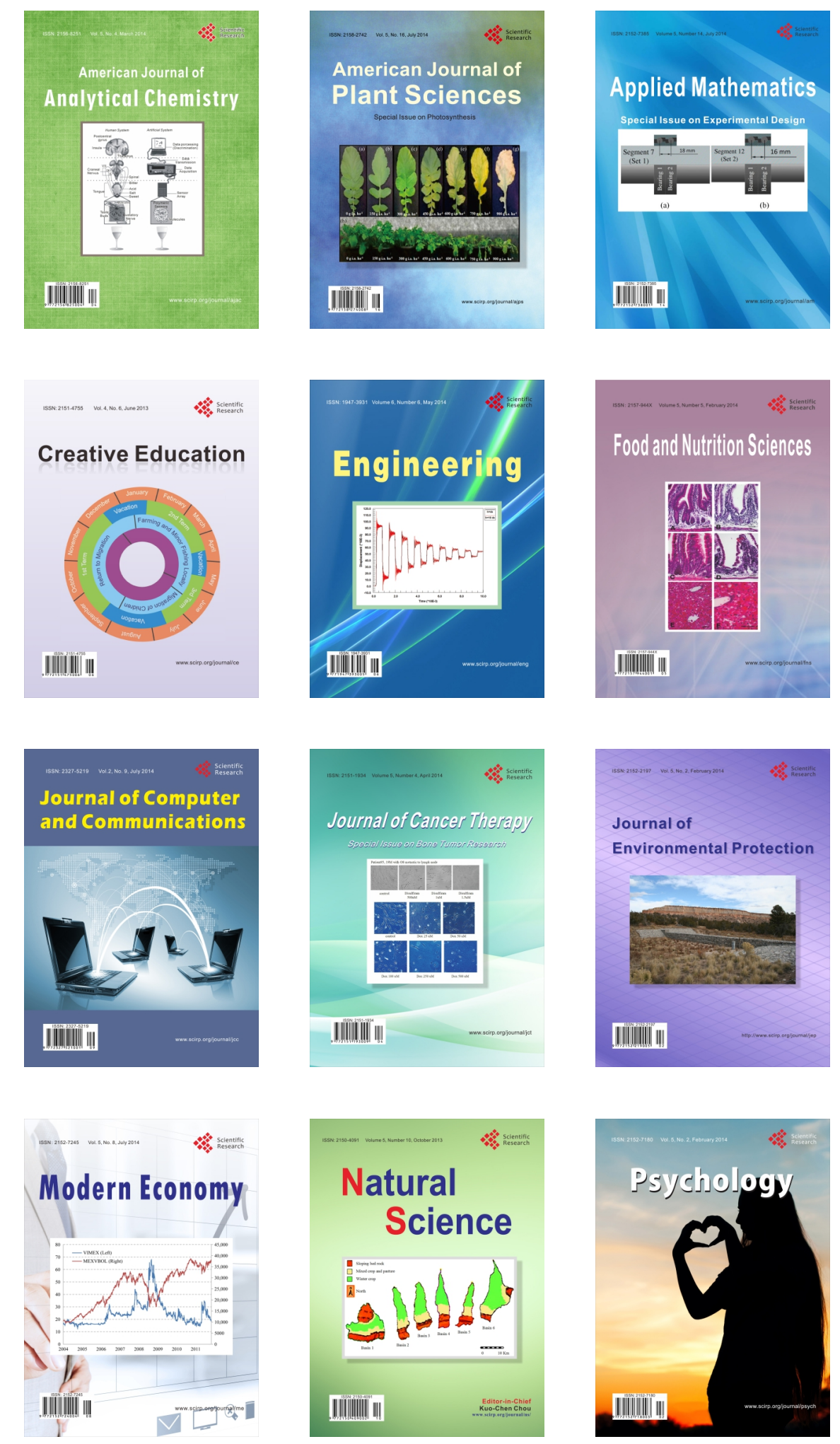